\title{
Periocular capillary hemangioma in 2018: natural course, indications for treatment and therapeutic options
}

\section{Hemangioma capilar periocular en 2018: curso natural, indicaciones para el tratamiento y opciones terapéuticas}

\author{
Carlos Fleitman-Broder* \\ Centro Médico ABC, Mexico City, México
}

\begin{abstract}
Capillary hemangiomas are one of the most common benign orbital and eyelid childhood tumors. Many of these tumors do not require treatment because they regress spontaneously without leaving sequelae; however, treatment is necessary in many cases, such as amblyogenic or eye-threatening lesions. Treatment of this kind of lesions has evolved from surgical excision to laser and steroids, all of them successful in different ways and with a range of side effects. In the last few years treatment has been revolutionized due to a casual finding made by Leaute-Labreze et al. Nowadays we use beta-blockers that have proved to be highly effective and with a much safer profile than previously used drugs. Several case reports have shown success by treating these lesions with topical beta-blockers. With this safer and more effective treatment, we can currently treat this lesions that in the past were just kept under observation, diminishing the cosmetic sequelae and the social stigma of patients having such lesions in their facial area.
\end{abstract}

Key words: Eyelid neoplasms (therapy). Hemangioma, capillary (therapy). Orbital neoplasms (therapy). Propranolol (therapeutic use). Facial neoplasms (therapy).

\section{Resumen}

Los hemangiomas capilares son el tumor de párpado y órbita más común en la infancia. La mayoría de estos tumores no requieren tratamiento, gracias a que involucionan espontáneamente sin dejar secuelas permanentes; sin embargo, en muchos casos, el tratamiento es necesario, por ejemplo, en el caso de lesiones ambliogénicas o que pongan en riesgo la salud ocular. El tratamiento de este tipo de lesiones ha evolucionado a lo largo de los años, desde la escisión quirúrgica, pasando por el láser y los tratamientos con esteroides, todos ellos con diferentes grados de éxito y efectos secundarios. En los últimos años, gracias a un hallazgo casual de Leaute-Labreze, et al., el tratamiento de estas lesiones ha sufrido una revolución. Ahora, en el arsenal terapéutico para este tipo de lesiones contamos con fármacos betabloqueadores, que han demostrado ser altamente efectivos y con un rango de seguridad mucho mayor que los tratamientos previamente utilizados. Hoy en día existen también reportes de casos que demuestran éxito en el tratamiento de estas lesiones con aplicación tópica de esta familia de medicamentos, lo que disminuye los efectos secundarios. Al contar con modalidades terapéuticas más seguras y eficaces, es posible tratar hemangiomas que en el pasado solamente se hubieran

\section{Correspondence:}

${ }^{*}$ Carlos Fleitman-Broder

Av. Vasco de Quiroga,

4001, Torre A, 5. ${ }^{\circ}$ Cons. 2 ,

Col. Santa Fe, Del. Cuajimalpa, Date of reception: 26-09-2018

Mexico City, Mexico

E-mail: cfleitman@gmail.com

Date of reception: $26-09-2018$
Date of acceptance: $26-02-2019$
DOI: $10.24875 / R M O E . M 19000065$
Available online: 08-05-2019 Rev MexOftalmol(Eng).2019;93(3):118-124 www.rmo.com.mx
r the CC BY-NC-ND license (http://creativecommons.org/licenses/by-nc-nd/4.0/). 
observado, así, se disminuyen las secuelas cosméticas y el estigma social que estos niños viven al tener una lesión de esta naturaleza en el área facial.

Palabras clave: (Tratamiento de) Neoplasias palpebrales. (Tratamiento de) Hemangioma capilar. (Tratamiento de) Neoplasias orbitales. (Uso terapéutico) Propanolol. (Tratamiento de) Neoplasias faciales.

\section{Introduction}

Capillary hemangiomas are one of the most common benign orbital and eyelid childhood tumors. They are composed of abnormal capillaries with proliferation of endothelial cells ${ }^{1-4}$.

The most common presentation of the hemangioma is that of a red colored tumor with a multi-lobed appearance (Fig. 1). If it is superficial or bluish (Fig. 2), if it is subdermal, or if it is a mass in the anterior part of the orbit, it usually increases in size during the first years of life, and then involutes spontaneously. Most hemangiomas pose no threat to visual development, but if they are large lesions, they can cause amblyopia due to mechanical ptosis, astigmatism, severe proptosis with exposure keratopathy and/ or optic nerve damage, depending on the location of the tumor. Visual development begins very early in childhood, and deprivation of visual stimulation during the first year of life has been shown to be detrimental to visual development. Studies have shown that total obstruction of the visual axis for a period of 1 week between birth and 1-year of age, can lead to amblyopia; therefore, the identification and appropriate and timely treatment of this type of tumors is of utmost importance ${ }^{1-3,5,6}$.

The histopathological characteristics of this vascular hamartoma varies depending on the clinical phase. In the early proliferative phase, the tumor consists mostly of endothelial cells, and vascular spaces are rare, likewise, it contains numerous mast cells. In more mature tumors, larger vascular spaces are observed, with a lower number of endothelial cells (Fig. 3). The tumor does not encapsulate and, generally, does not tend to infiltrate the surrounding structures. In the involutional phase there is often deposition of fibrous and adipose tissue around and inside the lesion ${ }^{3}$.

\section{Pathogenesis}

Hemangiomas are the most common childhood tumors, with a prevalence among infants of 5 to $12 \%$ and a female/male ratio of 3:1. The prevalence of periorbital and eyelid hemangiomas is from 1 to $3 \%$. No inheritance pattern has been found $d^{1-3}$.

There is no classification for hemangiomas; however, many authors classify them based on the depth.

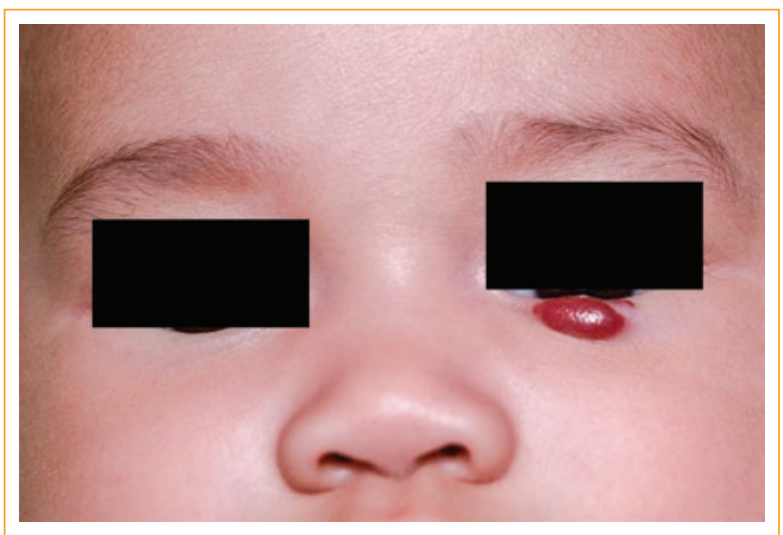

Figure 1. Superficial capillary hemangioma, lower left eyelid.

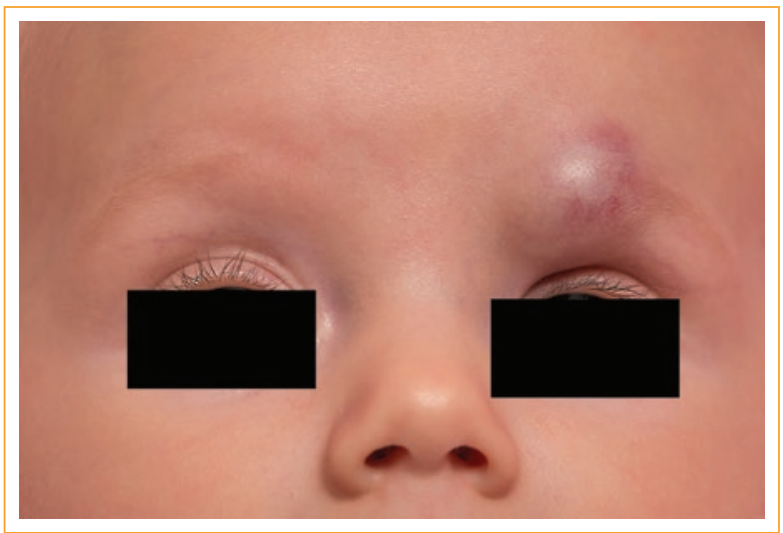

Figure 2. Deep capillary hemangioma of the left eyebrow.

Superficial or capillary hemangiomas, historically designated as "strawberry hemangiomas", develop from the papillary dermis, not as deep or cavernous hemangiomas that are located within the reticular dermis and subcutaneous tissue ${ }^{5}$.

Systemic complications associated with capillary hemangiomas include PHACE syndrome ((P)osterior fossa and other structural brain malformations; $(\mathrm{H})$ emangiomas; (A)rteries anomalies; (C)ardiac anomalies/(C)oarctation of the aorta; and (E)ye abnormalities), as well as visceral involvement of this tumors ${ }^{1-3,5}$. 


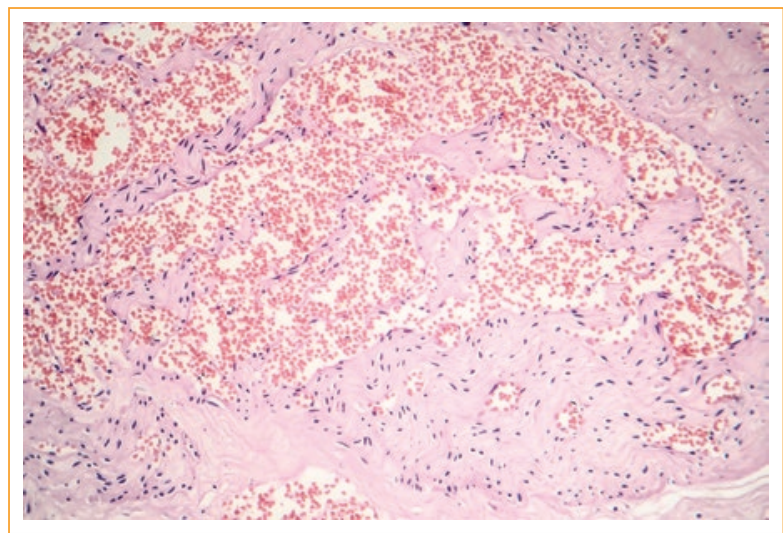

Figure 3. Histopathological section of a capillary hemangioma with endothelial proliferation and multiple vascular spaces ( $\mathrm{HE}, 40 \mathrm{x})$.

The exact pathogenesis of hemangiomas is not clear, but studies suggest that angiogenesis and vasculogenesis play an important role. It is speculated that there is a developmental defect during weeks 8 to 10 of gestational age that causes the formation of abnormal vessels by an endothelial precursor, which contributes to the process of pathological angiogenesis ${ }^{3}$.

During the postnatal proliferative phase, this tumor expresses numerous cellular markers of angiogenesis (vascular endothelial growth factor [VEGF], basic fibroblast growth factor [BFGF], type IV collagenase). Likewise, a lack of expression of substances that inhibit angiogenesis has been found. The incomplete vascular maturation observed in premature infants has also been associated with a higher incidence of capillary hemangiomas ${ }^{5}$.

One of the most accepted theories about the origin of capillary hemangiomas speculates that these originate from angioblastic tissue of the placenta, since they share some microvascular characteristics with placental tissue. North, et al. identified immunohistochemical markers common to placental tissue and histopathological samples of capillary hemangiomas, including glucose transporter-1 (GLUT1), immunoglobulin Fc receptor type II (FcgRII), merosin and Lewis-Y antigen ${ }^{5,7}$. Barnes, et al. demonstrated a similarity in the transcriptomes of hemangiomas and placental tissue. This reinforced, from a genetic point of view, the placental origin theory of the capillary hemangioma ${ }^{5,8}$.

One of the risk factors for developing capillary hemangiomas is chorionic villus sampling that could potentially seed metastatic placental tissue in remote areas, inducing the formation of this type of tumors ${ }^{5}$.

\section{Clinical characteristics and diagnosis}

Approximately one third of capillary hemangiomas are present at birth, and the rest will have appeared at the age of 6 months. The appearance of the tumor is usually preceded by a mild cutaneous erythema ${ }^{3}$.

The rapid growth lasts approximately 3 to 6 months, followed by a period of stabilization and then, usually, regression. At 7 to 9 years of age, 76 to $90 \%$ of hemangiomas will have involuted without any treatment. However, in 40 to $50 \%$ of cases, sequelae of the tumor persist, such as telangiectasia, fibrous and residual adipose tissue and/or abnormal scarring ${ }^{1-3}$.

Capillary hemangiomas are most commonly located in the upper eyelid or in the upper aspect of the orbit. Its appearance varies according to the depth; superficial skin lesions have a red lobed appearance, have been commonly described as "strawberry hemangiomas", and can increase in size and take a bluish color during weeping. Subcutaneous hemangiomas appear as a soft bluish mass, with signs and symptoms corresponding to an orbital mass (proptosis, compressive optic neuropathy, etc. $)^{1-3,5}$.

The development of amblyopia secondary to occlusion of the visual axis, astigmatism, anisometropia, strabismus due to compression of the eyeball or extension of the tumor to the retrobulbar space, is the most common complication, with an incidence ranging from $43 \%$ to $60 \%$.

The diagnosis can be clinically established in most cases; however, in some cases imaging studies may be necessary to rule out visceral involvement or aggressive neoplasms.

The differential diagnosis includes angioblastoma, neuroblastoma, rhabdomyosarcoma, fibrosarcoma, hemangiopericytoma and childhood myofibrosis ${ }^{5}$.

Doppler ultrasound can be useful in cases difficult to diagnose, demonstrating a pattern of high flow, asymmetry and acoustic irregularity, unlike solid tumors and vascular malformations that exhibit a low-flow pattern.

In computerized axial tomography, capillary hemangiomas show a homogenous mass enhanced by contrast medium. Sometimes it is possible to demonstrate the presence of blood vessels that nourish the tumor. Magnetic resonance imaging shows a lobulated lesion with an intermediate signal intensity, which is isointense with the extraocular muscles on $\mathrm{T} 1$ and hyperintense on $\mathrm{T}^{3,5}$.

Rarely, it is necessary to perform a biopsy to obtain histopathological confirmation of the tumor. 


\section{Treatment, when and how to treat?}

Periorbital and eyelid hemangiomas are associated with complications that can have a great effect on visual quality if they are not treated in a timely manner. In many cases, observation and expectant management are sufficient, since these lesions involute spontaneously.

The presence of an amblyogenic lesion is the most common indication for treatment. Other less common indications are rapid tumor growth, compressive optic neuropathy, and proptosis with exposure keratopathy ${ }^{1-6,9}$.

The anxiety of the parents due to the cosmetic defect that these injuries cause, can pose an important therapeutic challenge that should not be ignored. Other relative indications for treatment are ulceration, bleeding and infection.

There are many different strategies for the treatment of capillary hemangiomas. However, because these lesions undergo spontaneous regression and existing treatments are not free of side effects, treatment is usually reserved for lesions with a potential for complications.

The most common treatments recently available include corticosteroids, laser and surgical resection. Some treatments, such as cryotherapy, radiation and electrolysis, are practically obsolete nowadays. The use of immunomodulators such as cyclophosphamide and interferon alfa is reserved only as a second-line treatment for life-threatening or vision-threatening injuries. Finally, in recent years, treatment with beta-blockers has been increasingly accepted with excellent results, after the incidental discovery of Leaute-Labreze, et al. of the regression of capillary hemangiomas in patients who received propranolol for a cardiovascular indication ${ }^{10}$.

\section{Corticosteroid therapy}

Corticosteroids have been used in the treatment of capillary hemangiomas for more than four decades. Its mechanism of action to achieve involution of the lesion is still not understood. The treatment can be administered orally, intralesionally and/or topically, 5,11 .

Until recently, intralesional injection of corticosteroids was considered the first-line treatment for small, lowrisk lesions. The treatment is based on applying intralesionally $1-2 \mathrm{~mL}$ of a mixture of triamcinolone $(40 \mathrm{mg} /$ $\mathrm{mL}$ ) and betamethasone $(6 \mathrm{mg} / \mathrm{mL})$. A reduction in astigmatism of up to $1.4 \mathrm{D}$, or more, has been reported in 53.8 to $66 \%$ of patients; however, cutaneous side effects such as hypopigmentation and adipose tissue atrophy have been reported in up to $70 \%$ of patients, and isolated cases of palpebral necrosis, retinal central artery occlusion and ocular hypertension have also been reported ${ }^{5,11}$.

For large capillary hemangiomas, treatment with systemic corticosteroids can be considered. The regression of the lesion is observed in 2 weeks in $30 \%$ of the cases; however, in many cases it is necessary to prolong the treatment beyond 8 or 12 weeks. Boon et al. reported a series of 62 patients who received daily doses of less than $3 \mathrm{mg} / \mathrm{kg} /$ day for 1 month with progressive dose reduction over 2 to 3 months. Most of the side effects were temporary, while the patient was under treatment; one third of the patients suffered from stunting; however, $91 \%$ recovered within 2 years after steroid suspension. Personality changes were reported during treatment in $29 \%$ of the patients ${ }^{12}$.

The most important problem with corticosteroid treatment is poor response. The literature reports $11 \%$ to $30 \%$ of non-responders; also, some cases recur once treatment has been suspended ${ }^{5,6,11,13}$.

\section{Laser treatment}

Although Nd: YAG and $\mathrm{CO} 2$ lasers have been used as a treatment for capillary hemangioma with relatively acceptable results, nowadays pulsed laser is the laser of choice for this type of lesions s, $^{1,3,5}$.

The ideal wavelength for the treatment of capillary hemangiomas is from 585 to 600 nanometers $^{5}$.

Most experts recommend the use of laser only in early proliferation or late regression stages due to their low penetration. When the lesion is flat at its early stage, pulsed laser can be used at intervals of 4 to 6 weeks. Likewise, laser treatment can be used for residual telangiectasias secondary to an involutional hemangioma ${ }^{5}$.

\section{Surgical treatment}

Surgical treatment may be a good option in patients with a subcutaneous lesion with well-defined borders, or when other treatments have failed ${ }^{3,13}$.

The indications for surgical treatment are lack of response to medical treatment, rapid growth of the lesion and severe orbital and/or eyelid deformity. Many authors have reported good cosmetic and/or functional results with surgical treatment ${ }^{3,13}$.

The main adverse effects of surgical excision are scarring, hemorrhage and complications related to general anesthesia. There are isolated reports of lesions that required intraoperative blood transfusion ${ }^{13}$. 


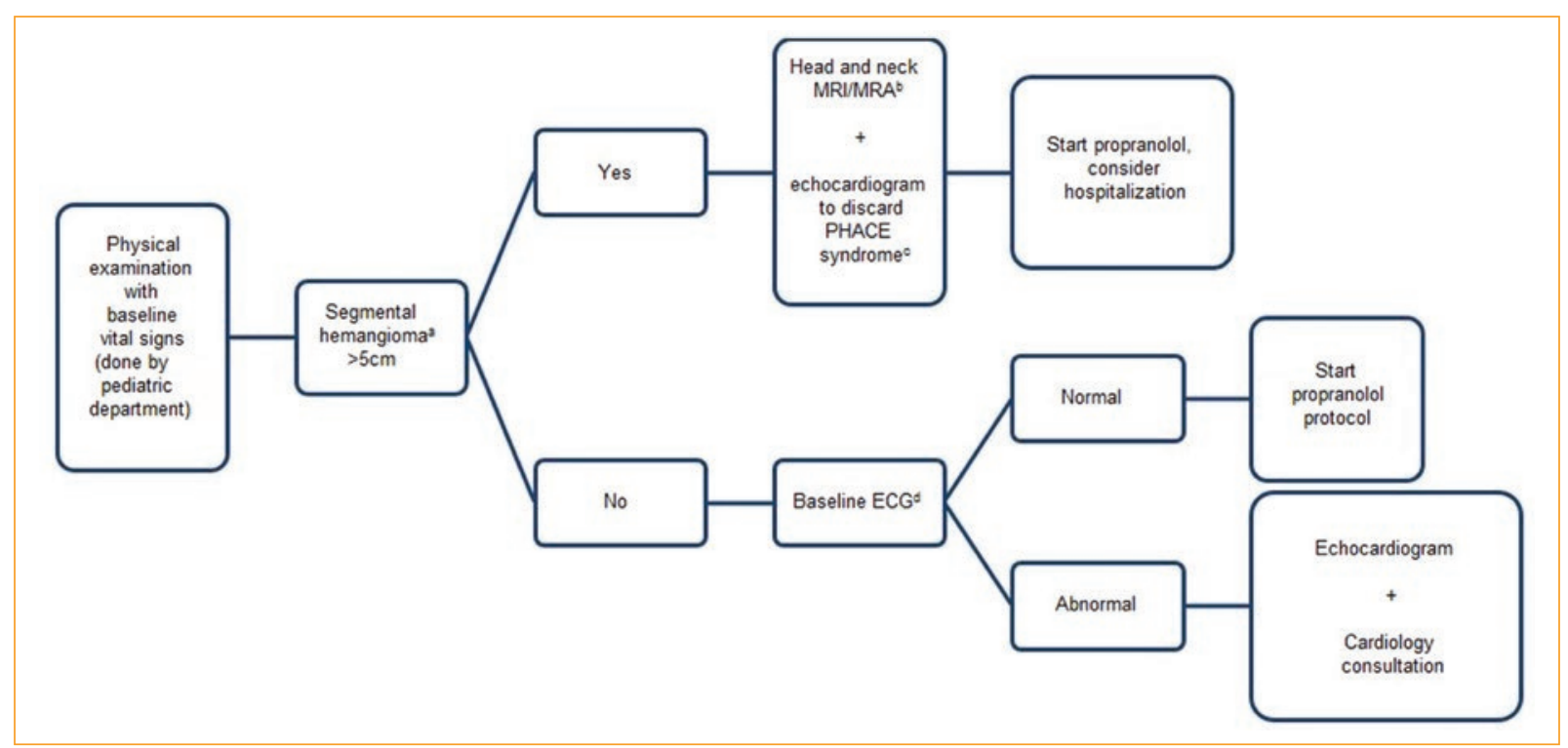

Figure 4. Protocol for the evaluation of patients prior to treatment with propranolol (modified from Haider, et al.16). aLobulated mass with a geographical configuration.

PHACE: (P)osterior fossa and other structural brain malformations; (H)emangiomas; (A)rteries anomalies; (C)ardiac anomalies/(C)oarctation of the aorta; and (E)ye abnormalities; NMR: nuclear magnetic resonance.

The main objective of early surgical excision is the prevention of amblyopia caused by astigmatism or visual deprivation. While late surgical treatment has a cosmetic goal.

\section{Immunotherapy and chemotherapy}

Immunomodulators are potent therapeutic agents with serious side effects; therefore, they are reserved for tumors that threaten the eye or life.

Cyclophosphamide with or without steroids has been used with good results ${ }^{4}$. Recent studies have also demonstrated the effectiveness of interferon alfa-2 (IFN-a2) for the treatment of capillary hemangioma ${ }^{3}$. Side effects of these medications include myelosuppression, hepatotoxicity and neurotoxicity. The long-term effects of IFN-a2 in the developing brain are unknown.

\section{Beta-adrenergic antagonists}

Leaute-Labreze, et al. noted that the administration of systemic propranolol in a child with hypertrophic cardiomyopathy caused the regression of a nasal capillary hemangioma. These same authors demonstrated a total of 11 cases of infantile hemangiomas successfully treated with $2 \mathrm{mg} / \mathrm{kg} /$ day of systemic propranolol for a period of up to 9 months $^{10}$.
After this finding, a large number of published reports have shown important regressions of hemangiomas in different parts of the body $4,9,14$.

The mechanism of action of propranolol in the reduction of hemangiomas has not been elucidated, but possible explanations include vasoconstriction, which is immediately visible as a change in coloration and a softer texture. Other factors that have been proposed as a mechanism of action are the decrease in the expression of different angiogenic factors, such as VEGF and BFGF, as well as an increase in the apoptosis of capillary endothelial cells $s^{4,5,10}$. Propanolol has a well-established safety and side effect profile. There is a lot of experience of its use in pediatric patients with cardiovascular disease and arterial hypertension. Although serious side effects have been demonstrated in infants who were exposed to beta-blockers in utero, postnatal exposure appears to be safe and free from serious side effects.

Adverse side reactions to beta-blockers include bradycardia, hypotension, hypoglycemia, gastroesophageal reflux, fatigue and bronchospasm ${ }^{5,15}$.

A clinical history and physical examination focused on cardiovascular and respiratory diseases is necessary before treatment administration. The most widely used protocol for this treatment is ${ }^{16}$ : 
Table 1. Protocol for the administration of propranolol (modified from Haider, et al. ${ }^{16}$ )

\begin{tabular}{|c|c|}
\hline Suspension & $20 \mathrm{mg} / 5 \mathrm{~mL}$ or $40 \mathrm{mg} / 5 \mathrm{~mL}$ \\
\hline Dose & $\begin{array}{l}0.5 \mathrm{mg} / \mathrm{kg} / \mathrm{day} \text { divided into } 3 \text { doses for } \\
2-3 \mathrm{days} \\
1.0 \mathrm{mg} / \mathrm{kg} / \text { day divided into } 3 \text { doses for } \\
2-3 \mathrm{days} \\
1.5 \mathrm{mg} / \mathrm{kg} / \text { day divided into } 3 \text { doses for } \\
2-3 \mathrm{days} \\
2.0 \mathrm{mg} / \mathrm{kg} / \text { day divided into } 3 \text { doses (final) }\end{array}$ \\
\hline Monitoring & $\begin{array}{l}\text { Measure blood pressure }+ \text { heart rate } 24 \mathrm{~h} \\
\text { after each dose change }\end{array}$ \\
\hline Discontinuation & Decrease the dose gradually for 2 weeks \\
\hline
\end{tabular}

- Baseline echocardiography and a 48-hour hospitalization for pre-treatment vital signs monitoring.

- Administration of propranolol $0.16 \mathrm{mg} / \mathrm{kg}$ every $8 \mathrm{~h}$ as starting dose.

- Increase the dose to a maximum of $0.67 \mathrm{mg} / \mathrm{kg}$ every 8 hours ( $2 \mathrm{mg} / \mathrm{kg} /$ day) if vital signs and blood glucose allow it.

- The treatment must be maintained during the proliferative phase of the hemangioma or until there is no visible improvement.

- Gradual reduction of the dose for a period of 2 weeks.

Haider et al. published a protocol in 2010 for the treatment with oral propranolol without the need for hospitalization (Fig. 4) in 17 patients and achieved growth detention or size decrease of all treated lesions. There were only mild side effects in 6 of these patients, and there was no need to suspend treatment in any patient $^{17}$ (Table 1).

Guo, al. reported for the first time the effectiveness of $0.5 \%$ topical timolol solution applied directly on the surface of the lesion ${ }^{18}$. Since then, several studies have shown the effectiveness of topical treatment with $0.5 \%$ timolol solution or $0.1 \%$ gel 3 or 4 times a day, with an excellent safety profile. Likewise, it has been shown that the capillary hemangiomas that best respond to this treatment are the superficial ones and those that are in the proliferative phase $\mathrm{e}^{16,18-24}$.

In most referral centers, topical or systemic beta-blockers, depending on the characteristics of the lesion, are nowadays the first-line treatment for this type of lesions.

\section{Conclusions}

Capillary hemangiomas are the most common periocular tumors in childhood and represent an important risk factor for visual loss and amblyopia even though the natural history of the disease is spontaneous regression.

The identification and treatment of amblyogenic lesions is extremely important, as well as the monitoring of cases in which the risk of evolving towards an amblyogenic lesion is high.

Currently, beta-adrenergic antagonists have revolutionized the treatment of these injuries, giving an invaluable option to the therapeutic arsenal, with excellent results and safety profile.

Nowadays, the gold standard for the treatment of capillary hemangiomas is, without a doubt, the treatment with beta-blockers, either systemic or topical, depending on the type of hemangioma. With this safer and more effective treatment, we can currently treat this lesions that in the past were just kept under observation, diminishing the cosmetic sequelae and the social stigma of patients having such lesions in their facial area.

\section{Conflicts of interest}

The author declares no conflict of interests with any of the contents or medications mentioned in this article.

\section{Ethical disclosures}

Protection of human and animal subjects. The authors declare that no experiments were performed on humans or animals for this study.

Confidentiality of data. The authors declare that they have followed the protocols of their work center on the publication of patient data.

Right to privacy and informed consent. The authors have obtained the written informed consent of the patients or subjects mentioned in the article. The corresponding author is in possession of this document.

\section{References}

1. Hoyt C, Taylor D. Pediatric Ophthalmology and Strabismus. $3^{\text {rd }}$ ed. Philadelphia: Elsevier Saunders; 2005.

2. Nelson LB, Olitsky SE. Harley's Pediatric Ophthalmology. $5^{\text {th }}$ ed. Philadelphia: Lippincott Williams \& Wilkins; 2005.

3. Shields JA, Shields CL. Eyelid, Conjunctival, and Orbital Tumors. $2^{\text {nd }}$ ed. Philadelphia: Lippincot Williams \& Wilkins; 2008.

4. Fabian ID, Ben-Zion I, Samuel C, Spierer A. Reduction in astigmatism using propranolol as first-line therapy for periocular capillary hemangioma. Am J Ophthalmol. 2011:151(1):53-8.

5. Ni N, Wagner RS, Langer P, Guo S. New Developments in the Management of Periocular Capillary Hemangioma in Children. J Pediatr Ophthalmol Strabismus. 2011:48(5):269-76.

6. Frank RC, Cowan BJ, Harrop AR, Astle WF, McPhalen DF. Visual development in infants: visual complications of periocular hemangiomas. J Plast Reconstr Aesthet Surg. 2010;63(1):1-8.

7. North PE, Waner M, Mizeracki A, Mihm JMC. GLUT1: a newly discovered immunohistochemical marker for juvenile hemangiomas. Hum Pathol. 2000;31(1):11-22. 
Rev Mex Oftalmol (Eng). 2019;93

8. Barnes CM, Huang S, Kaipainen A, Sanoudou D, Chen EJ, Eichler GS et al. Evidence by molecular profiling for a placental origin of infantile hemangioma. Proc Nat Acad Sci USA. 2005;102(52):19097-102.

9. Zimmermann AP, Wiegand S, Werner JA, Eivazi B. Propranolol therapy for infantile haemangiomas: Review of the literature. Int J Pediatr Otorhinolaryngol. 2010;74(4):338-42.

10. Léauté-Labrèze $C$, Dumas de la Roque $E$, Hubiche $T$, Boralevi $F$, Thambo JB, Taïeb A. Propranolol for severe haemangiomas of infancy. N Engl J Med. 2008;358(24):2649-51.

11. Gawley SD, Bingham EA, McGinnity G. Visual outcomes of treated periocular capillary haemangiomas in childhood: a10-year review. Acta Ophthalmol. 2011;89(4):396-401.

12. Boon LM, MacDonald DM, Mulliken JB. Complications of systemic corticosteroid therapy for problematic hemangioma. Plast Reconstr Surg. 1999:104(6):1616-23

13. Arneja JS, Mulliken JB. Resection of amblyogenic periocular hemangiomas: indications and outcomes. Plast Reconstr Surg. 2010; 125(1):274-81.

14. Greinwald JH Jr, Burke DK, Bonthius DJ, Bauman NM, Smith RJ. An update on the treatment of hemangiomas in children with interferon alfa-2a. Arch Otolaryngol Head Neck Surg. 1999;125(1):21-7.

15. Chen TS, Eichenfield LF, Friedlander SF. Infantile hemangiomas: an update on pathogenesis and therapy. Pediatrics. 2013;131(1):99-108.
16. Ni N Langer P, Wagner R, Guo S. Topical Timolol for Periocular Hemangioma: Report of Further Study. Arch Ophthalmol. 2011;129(3):373-9.

17. Haider KM, Plager DA, Neely DE, Eikenberry J, Haggstrom A. Outpatient treatment of periocular infantile hemangiomas with oral propranolol. JAAPOS. 2010;14(3):251-6.

18. Guo S, Ni N. Topical Treatment for Capillary Hemangioma of the Eyelid Using $\beta$-Blocker Solution. Arch Ophthalmol. 2010;128(2):255-6.

19. Semkova K, Kazandjieva J. Topical timolol maleate for treatment of infantile haemangiomas: preliminary results of a prospective study. Clin Exp Dermatol. 2013;38(2):143-6.

20. Jha AK, Mallik SK, Raihan M. Topical ophthalmic solution in infantile hemangioma. J Postgrad Med. 2012;58(2):163-5.

21. Moehrle M, Léauté-Labrèze C, Schmidt V, Röcken M, Poets CF, Goelz R. Topical Timolol for Small Hemangiomas of Infancy. Pediatr Dermatol. 2013;30(2):245-9.

22. Calvo M, Garcia-Millán C, Villegas C, Fueyo-Casado A, Burón I. Topical timolol for infantile hemangioma of the eyelid. Int J Dermatol. 2013;52(5):603-4.

23. Chambers CB, Katowitz WR, Katowitz JA, Binenbaum G. A Controlled Study of Topical $0.25 \%$ Timolol Maleate Gel for the Treatment of Cutaneous Infantile Capillary Hemangiomas. Ophthal Plast Reconstr Surg. 2012;28(2):103-6.

24. Oranje AP, Janmohamed SR, Madern GC, de Laat PC. Treatment of Small Superficial Haemangioma with Timolol 0.5\% Ophthalmic Solution: A Series of 20 Cases. Dermatology. 2011;223(4):330-4. 